\title{
Floating faeces for a cleaner fish production
}

\author{
Julia Unger $^{1,2}$, Mark Schumann ${ }^{1,2}$, Alexander Brinker ${ }^{1, *}$ \\ ${ }^{1}$ Fisheries Research Station of Baden-Württemberg, Argenweg 50/1, 88085 Langenargen, Germany \\ ${ }^{2}$ Limnological Institute, University of Konstanz, 78457 Konstanz, Germany
}

\begin{abstract}
Recent developments in European recirculating aquaculture systems suggest expanding potential for this extremely water-efficient technique. However, the technology still faces challenges due to concerns over economic efficiency and system stability - both essential in minimizing the risk of financially and environmentally expensive failures. One key factor in maintaining stable production conditions in a recirculation loop is the effective removal of solid waste, i.e. fish faeces. This study tested a novel approach for solid control and demonstrates the value-adding potential of floating faeces under commercial conditions in a semi-recirculating fish farm in Germany. A commercial control diet was compared with an experimental diet in which the addition of $2.5 \%$ cork granules led to the production of floating faeces. Physiological assays indicated no pathologic tissue alterations associated with the experimental feed, and growth, survival and feed conversion were unaffected. Average single-pass removal by a specially developed surface separator accounted for $78.3 \%$ of floating solids, which accounted for $35.4 \%$ of total system solids. Total ammonia nitrogen concentrations in production water were roughly halved, from about $0.95 \mathrm{mg} \mathrm{l}^{-1}$ in the control to $0.47 \mathrm{mg} \mathrm{l}^{-1}$ using the cork diet, an improvement that in practice allowed a doubling of production on the same available water flow. This study shows that the application of floating faeces facilitates rapid and cost-effective removal of suspended solids, resulting in a considerable decrease of nutrient load in system and discharge water of the investigated farm.
\end{abstract}

KEY WORDS: Fish welfare $\cdot$ Functional feed $\cdot$ Cork $\cdot$ Biofilter $\cdot$ Effluent management $\cdot$ Solid waste $\cdot$ Recirculating system $\cdot$ Water use efficiency

\section{INTRODUCTION}

The rising global demand for fish and seafood is set to continue, concomitant with world human population growth and increasing awareness in developed countries of the health benefits of eating fish (Merino et al. 2012). Wild stock levels place an upper limit on production in capture fisheries, leaving the intensification of aquaculture as the only option for meeting future demand. Consequently, aquaculture is already the fastest-growing animal-food-producing sector and is likely to remain so into the foreseeable future (FAO 2014). However, environmentally aware consumers worldwide are also pressing for more responsible methods of food production, and thus aquaculture is subject to increasingly stringent regulation, in particular with respect to effluent management

\footnotetext{
${ }^{*}$ Corresponding author: alexander.brinker@lazbw.bwl.de
}

(Jensen et al. 2011). The increasing demand for fish and seafood and the limitations on access to water and land suitable for production create an urgent need for further modernisation and improvement in aquacultural technologies. In recent decades, recirculating aquacultural systems (RAS) have shown considerable promise in the search for more sustainable methods (Martins et al. 2010). However, despite continuous development and notable improvements in system design, this intensive method of fish farming faces diverse challenges and is still far from meeting market demand for grow-out fish, even in developed countries. A holistic approach, working towards competent and cost-effective handling of all system components, is timely, and the identification of new techniques that tackle problems at their source and enable easy and cost-effective system

() The authors 2015. Open Access under Creative Commons by Attribution Licence. Use, distribution and reproduction are unrestricted. Authors and original publication must be credited. 
management will be key in the future sustainability and profitability of the industry (Klinger \& Naylor 2012).

A key aspect of effective solid waste management in aquaculture is the removal of suspended solids: a recent survey of researchers, consultants, suppliers and production companies identified solids management and biofilter operation and management as the most difficult technical issues in RAS (Badiola et al. 2012). Despite negligible effluents emanating from closed systems, waste management is a serious concern in RAS due to the problems associated with the accumulation of fine solids (Davidson et al. 2013).

Suspended solids can have a decisive impact on the performance of the whole system. Nutrients such as phosphorus and nitrogen leached from solid waste into solution are much more difficult to remove (Stewart et al. 2006). Fine particles derived from the degradation of suspended faecal particles impair fish health (Bilotta \& Brazier 2008), hamper biofilter efficiency by clogging and lead to imbalances in bacterial populations (Ling \& Chen 2005), with a consequent accumulation of toxic compounds such as ammonia and nitrite. Theoretically, mechanical treatment options are available to remedy this, but in practice, thresholds for even state-of-the-art techniques are easily exceeded. For example, where microsieves are used, smaller mesh sizes can enhance efficiency, but the concomitant increases in backpressure and backwashing requirements (Cripps \& Bergheim 2000) lead to exponentially increasing operating costs. Thus a more practical solution is to reduce the production of small particles $(<100 \mu \mathrm{m})$ as far as possible. In order to limit the fragmentation of larger particles, microbial degradation and leaching of soluble nutrients, solids must be removed from the system as quickly and gently as possible, minimizing water contact time and shear force exposure (McMillan et al. 2003, Brinker et al. 2005a)

The composition of fish feed has considerable influence on the properties of resulting faecal waste (Davidson et al. 2013, Dolan et al. 2013). The market for raw ingredients is dynamic, and regular changes in feed composition have been the norm, with little or no opportunity to assess potential consequences, let alone mitigate against negative ones. However, it is possible to manipulate the properties of faeces in such a way as to increase mechanical and chemical stability (Brinker \& Friedrich 2012) and limit the production of fine particles (Unger \& Brinker 2013a). A further promising approach has been the use of functional feed ingredients to reduce faecal density, resulting in the production of floating faeces (Unger
\& Brinker 2013b) and facilitating rapid and effective waste management in several ways:

- Allowing rapid and almost complete removal of faecal casts

- Minimizing leaching of soluble components

- Ensuring improved biofilter efficiency and stability

- Reducing investment and operating costs by limiting the requirement for solid treatment to surface flow only

- Improving water quality and feed utilization, with additional benefits in terms of stock health and welfare

- Production of fertilizer-quality sludge, with no need for further thickening

Based on extensive laboratory studies (Unger \& Brinker 2013b) showing that inclusion of low levels of cork Quercus suber L. granules in trout diet produced faecal casts which float, the present study applies the approach to a commercial environment, examining the effect of an experimental diet and floating faeces on stock health and performance, removal efficiencies (by sedimentation, drum filtration and surface separation), biofilter performance and sludge quality in an operational fish farm, and comparing the outcomes with those of a commercial control diet.

\section{MATERIALS AND METHODS}

\section{Routine fish farm operations}

The field survey was carried out in a commercial land-based semi-recirculating rainbow trout Oncorhynchus mykiss farm in southern Germany between 6 June and 4 August 2011. The supply of fresh water was derived from trout ponds above the farm that had been treated by passing through 2 settling ponds $\left(45-55 \mathrm{l} \mathrm{s}^{-1}\right)$ and a fixed-bed filter (average hydraulic retention time: $0.51 \mathrm{~h}$ ). The exchange rate of system water during the study period was between 3 and 6 times $\mathrm{d}^{-1}$. The system comprised 5 serially installed raceways (R1-R5; Fig. 1).

Each raceway measured $21 \mathrm{~m}$ in length, was $2.90 \mathrm{~m}$ wide and had a water depth of $1.55 \mathrm{~m}$. Two raceways (R4 and R5) constituted the static biofilters $\left(45.15 \mathrm{~m}^{2}\right.$, flow rate: 110-120 $\mathrm{l} \mathrm{s}^{-1}$, material: Hel-x [HX17KLL], Stöhr), with R5 and R4 treating water from the upper ponds and from the recirculating system, respectively. R1 and R2 were used entirely for fish production. Most of R3 was used for fish production during the cork trial, and roughly half during the control trial, when additional space was required for settling 


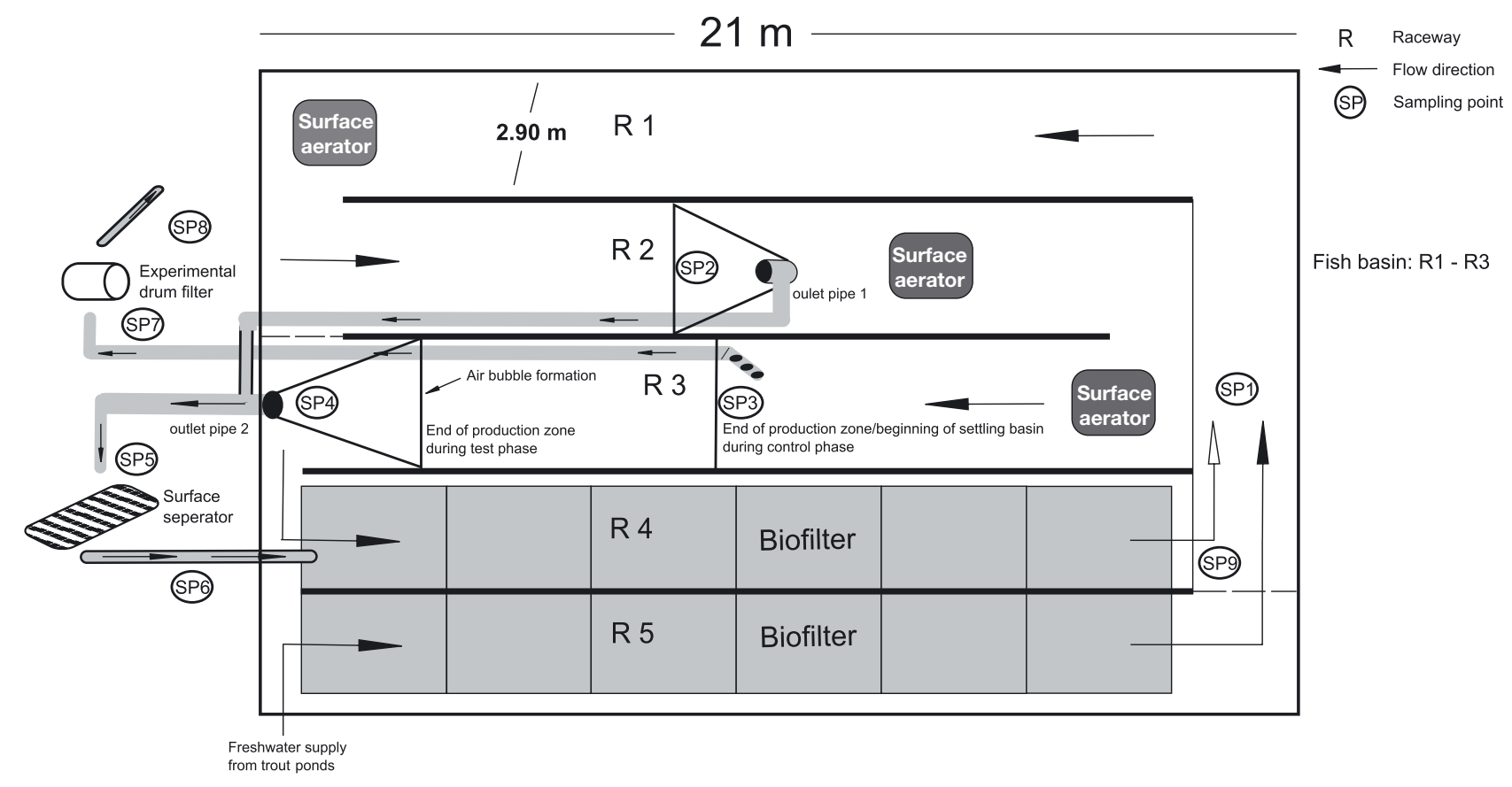

Fig. 1. Diagram of the fish farm, showing raceways (R), aeration units (FAS KR 94/L, $0.37 \mathrm{~kW}$ ), surface separator settling basin and experimental drum filter (HDF-501-1P). Nine sampling points (SP) for analysis of water physicochemistry are shown as follows: SP1: system inlet, SP2: before outlet pipe 1, SP3: after production zone/before biofilter, SP4: before outlet pipe 2, SP5: before surface separator, SP6: after surface separator, SP7: before drum filter, SP8: after drum filter, SP9: biofilter outlet. Arrows indicate direction of water flow

(settling basin). Outlet pipes leading to the surface separator were installed in R2 (outlet pipe 1) and R3 (outlet pipe 2). The surface separator was a prototype designed by the project partners Fischzucht Zordel (Neuenbürg, Germany) and Genesis GmbH \& Co. KG (Pforzheim, Germany) to efficiently separate faeces from the water (see Fig. 2 for schematic drawing). Floating particles were lifted by a revolving belt loop, dewatering by gravity while being transported to a sludge box. Filtered water was led back to the biofilter inlet of R4.

The production raceways (R1-R3) were divided into 7 rearing compartments, housing fish of different size classes (R1 with the smallest fish to R3 with the largest fish). Temperature and oxygen levels were monitored continuously at several locations using electronic probes set to trigger automatic alarms in the event that any variable exceeded preset limits. Three surface oxygen aerators located at positions marked in Fig. 1 delivered constant aeration, and when oxygen levels fell below $6 \mathrm{mg} \mathrm{l}^{-1} \mathrm{O}_{2}$, pure oxygen was introduced directly to system water via a perforated tube. A further airlift pump provided continuous aeration of inlet water.

In addition to the solid control performed by the surface separator and sedimentation basin, a state- of-the-art drum filter (Hydrotech HDF- 501-1P) was also installed for purposes of comparing removal efficiencies. Production water for drum filtration was drawn from the full profile of the total water column at the end of the production zone (SP3). It was pumped by a special centrifugal pump (KSB GetecBloc L 100 - 74.1/ G S; nominal power: 1.9 kW; rotational speed: $62-220 \mathrm{~min}^{-1}$ ) through a braided hose (internal diameter $75 \mathrm{~mm}$ ) into the experimental drum filter (SP 7; Fig. 1) at about $101 \mathrm{~s} \mathrm{~s}^{-1}$. The pump is designed to generate minimal turbulence and pump shear force. The drum filter was equipped alternately with 2 different filter screens (30 and $100 \mu \mathrm{m})$, which were replaced every $4 \mathrm{~d}$ during each of the 2 trials.

\section{Feeding protocol}

A widely used commercial trout feed (Efico Enviro $921+0.3 \%$ guar gum) generating high-density faeces (mean \pm SE $1.0489 \pm 0.0012 \mathrm{~g} \mathrm{~m}^{-3}$; Unger \& Brinker 2013b) was used as a control diet (Table 1). The experimental diet was the same basic feed, supplemented with $2.5 \%$ cork granules (range of grain size: $0.5-1 \mathrm{~mm}_{\text {; }}$ Amorim; Fig. 3a). The cork was mixed with other components of the diet before 
Table 1. Commercial declaration of the control diet EFICO Enviro 921 (BioMar) plus guar gum (SEAH International). Control diet composition included fish meal (LT94), fish oil, soy concentrate, haemoglobin meal, rapeseed oil, pea protein, vitamins and minerals. For the trial, the basic diet was supplemented with $2.5 \%$ cork Quercus suber granules $(\varnothing 0.5-1 \mathrm{~mm}$, Amorim) as well as guar gum ('gomme de guar', HV 109 [Code: 3309]; SEAH International). NFE: nitrogen-free extract

\begin{tabular}{|lcc|}
\hline & \multicolumn{2}{c|}{ Pellet size } \\
& $3 \mathrm{~mm}$ & $4.5-6 \mathrm{~mm}$ \\
\hline Crude protein (\%) & 48.0 & 47.0 \\
Crude lipid (\%) & 25.0 & 26.0 \\
Carbohydrate (NFE) (\%) & 13.2 & 12.7 \\
Crude fibre (\%) & 0.8 & 0.8 \\
Ash (\%) & 7.0 & 7.5 \\
Phosphorus (\%) & 0.9 & 0.9 \\
Guar gum (\%) & 0.3 & 0.3 \\
Cork (\%) & 2.5 & 2.5 \\
Gross energy (MJ / kcal) & $23.7 / 5653$ & $23.7 / 5671$ \\
Digestible energy (MJ / kcal) & 21.2 / 5064 & $21.3 / 5096$ \\
\hline
\end{tabular}

extrusion so as to be homogeneously distributed in the matrix of feed pellets; an examination under a scanning electron microscope showed that cork particles survived the extrusion process intact (Fig. 3b).
Fish were fed the cork-free control diet for $17 \mathrm{~d}$, from 15 June until 1 July 2011. The cork-supplemented diet was then supplied for $23 \mathrm{~d}$, from 13 July until 4 August 2011. The extended schedule of the cork trial was due to some days on which heavy rainfall distorted measurements by importing fine sludge and sediment into the system. No data were recorded on these days.

Feeds were delivered by hand to apparent satiation of fish, twice daily from $07: 30$ to $08: 30 \mathrm{~h}$ and from 17:00 to 17:30 h. At the start of each phase of the trial, fish were given $1 \mathrm{wk}$ to adjust to the new diets before experimental recording began. As the trial was embedded into the standard routine of the fish farm, some fish were removed for sale during the experiment. The missing biomass was immediately restocked with fish of comparable size from another pond. Restocking amounted to $315 \mathrm{~kg}(0.4 \%$ of standing stock) during the control phase and $2256 \mathrm{~kg}$ ( $3.5 \%$ of standing stock) during the cork phase.

\section{Fish stock and feed utilization}

Stocking densities ranged from 49.5 to $62.2 \mathrm{~kg} \mathrm{~m}^{-3}$ during the control treatment and from 56.0 to $71.1 \mathrm{~kg}$

\section{Filter segment (top view)}

\section{Surface separator (side view)}

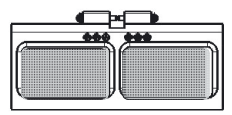

Mesh size $=1 \mathrm{~mm}$

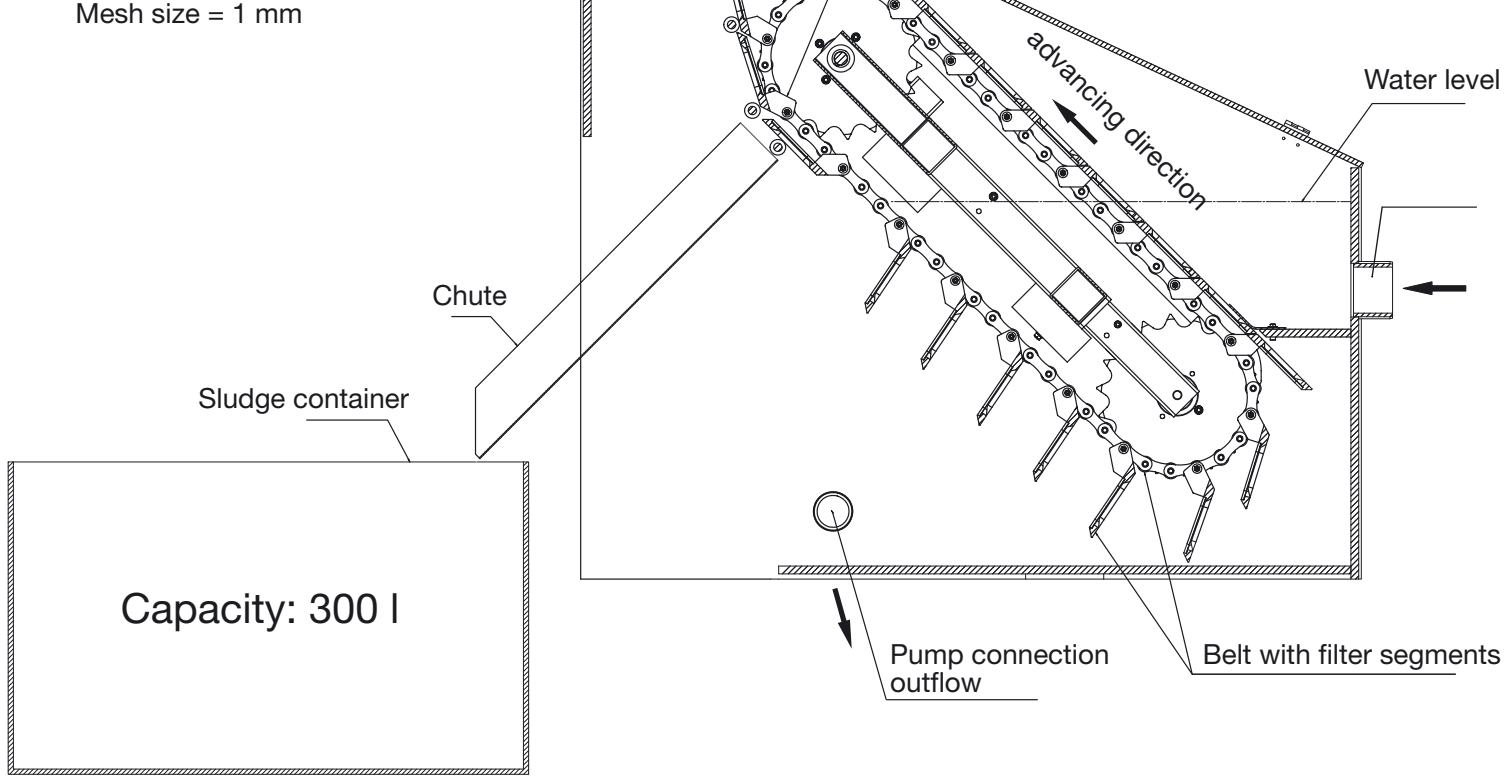

Fig. 2. Schematic of the surface separator. Water inflow/outflow and advancing direction is given by the arrows 
$\mathrm{m}^{-3}$ during the cork treatment. For each basin, weight gain of fish stock was derived from weights of representative samples taken at the beginning and at the end of each trial.

The feed conversion ratio (FCR) was calculated according to the equation:

$$
\mathrm{FCR}=\frac{\text { Feed }(\mathrm{kg})}{\text { Weight gain }(\mathrm{kg})}
$$

and the thermal growth coefficient (TGC) was calculated as per Iwama \& Tautz (1981):

$$
\mathrm{TGC}=\left(\frac{\sqrt[3]{W_{f}}-\sqrt[3]{W_{i}}}{d \times t}\right) \times 1000
$$

where $W_{f}$ is final weight $(\mathrm{kg}), W_{i}$ is initial weight $(\mathrm{kg}), d$ is number of days and $t$ is the average daily temperature $\left({ }^{\circ} \mathrm{C}\right)$.

Additional samples of 10 randomly selected fish were collected between the trials and a further 20 at the end of the experiment, for histological and pathological examination by the independent 'Staatliches Tierärztliches Untersuchungsamt (STUA) Diagnostikzentrum' (state veterinary examination office - diagnostics centre) in Aulendorf, Germany. The intestines were examined for signs of inflammatory infiltrates, calcification, necrosis, activation of macrophages and giant cells. The liver was investigated for inflammatory infiltrates (peribiliary, perivas- cular and in tissue), necrosis/cell loss and melanomacrophages.

On several dates during the experiment and at different times of the day, fish were sampled at random and dissected to check their stomachs for ingested faecal particles.

\section{Sampling of faeces}

Sampling of fresh faeces $(\mathrm{n}=72)$ took place at various points in time during the trial. Fish were anaesthetized with clove oil (concentration: $0.1 \mathrm{ml} \mathrm{l}^{-1}$, exposure time: ca. $60 \mathrm{~s}$ ) and faeces were stripped from the intestine by applying slight pressure with the fingers from the ventral fin to the anus. Measurements of faecal properties were taken immediately after sampling. Faeces removed from the system water by the surface separator were also sampled for analysis $(\mathrm{n}=8)$.

The density of intestinal faeces was measured immediately after sampling using an Anton Paar DMA 38 density meter (functionality described by Unger \& Brinker 2013a). The faeces of 10 fish were pooled for testing. As faecal density is influenced by water absorption (Unger \& Brinker 2013b), further samples were also measured after being allowed to soak for $1 \mathrm{~h}$ in water from the system (Table 2). This soaking time is based on the average retention of water in fish

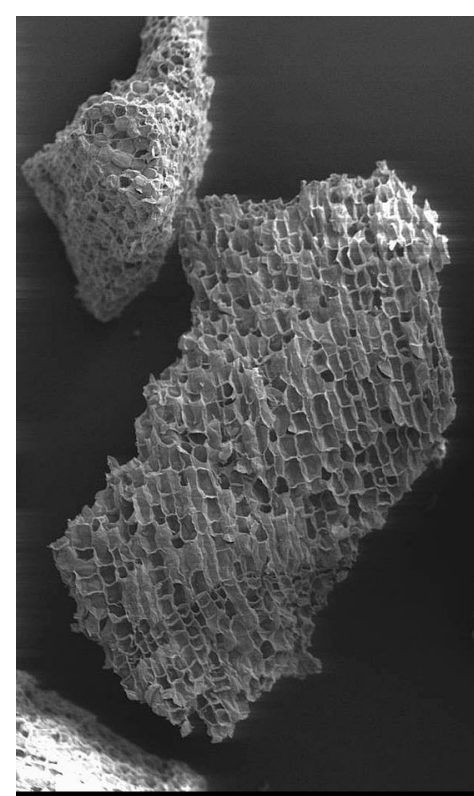

a)

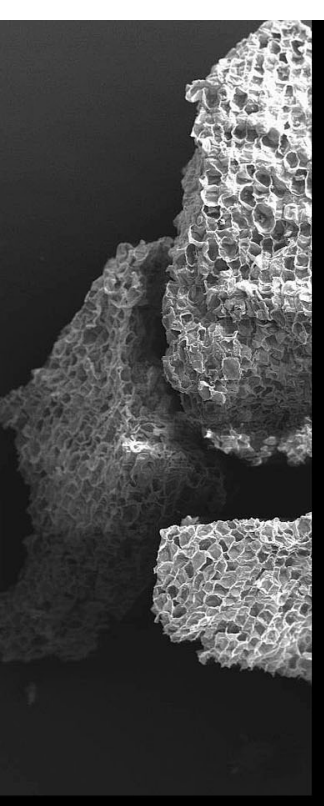

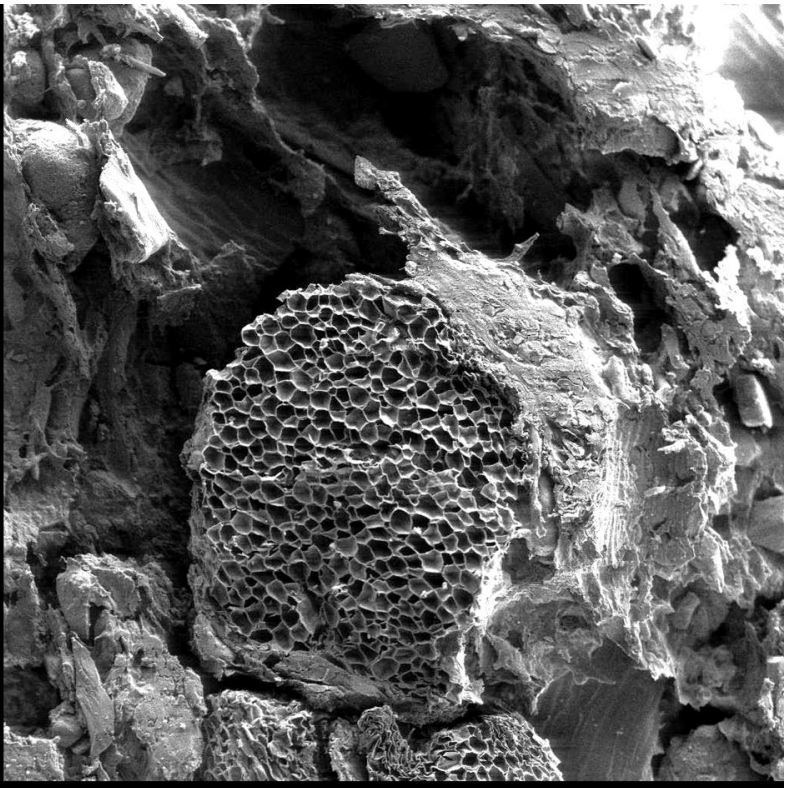

b)

Fig. 3. Scanning electron microscope images of (a) an individual cork Quercus suber particle, $\varnothing 0.5-1$ mm (Amorim) and (b) cork granules embedded in a feed pellet after extrusion 
Table 2. Sampling scheme of density measurements of faecal matter from rainbow trout Oncorhynchus mykiss collected during the 2 trials

\begin{tabular}{|lll|}
\hline $\begin{array}{l}\text { Sampling } \\
\text { days per } \\
\text { trial }\end{array}$ & $\begin{array}{l}\text { Fish size/ } \\
\text { sample type }\end{array}$ & Measuring state \\
\hline 2 & $\begin{array}{l}\text { Small fish } \\
(<150 \mathrm{~g})\end{array}$ & $\begin{array}{l}\text { Original (dissected) } \\
\text { Soaked in distilled water }(1 \mathrm{~h}) \\
\text { Soaked in system water }(1 \mathrm{~h})\end{array}$ \\
2 & $\begin{array}{l}\text { Plate-sized } \\
\text { fish }(>150 \mathrm{~g})\end{array}$ & $\begin{array}{l}\text { Original (dissected) } \\
\text { Soaked in distilled water }(1 \mathrm{~h}) \\
\text { Soaked in system water }(1 \mathrm{~h}) \\
\text { Original }\end{array}$ \\
2 & $\begin{array}{l}\text { Surface } \\
\text { separator }\end{array}$ & S \\
\hline
\end{tabular}

farms in southwest Germany (Brinker 2005). Each measurement was performed at least in duplicate.

\section{Water chemistry}

Water samples for analysis of basic physicochemical properties (see Table 3) were collected on 3 occasions: (1) before the trial (9 June 2011), (2) in between trials when the diets were changed (6 July 2011) and (3) shortly before the end of the trial (1 August 2011) at 4 different locations: the system inlet; before the drum filter; before the biofilter and after the biofilter (latter sample characterized as effluent). Values for all parameters evaluated remained stable throughout the trial (Table 3).

Further water samples were collected and analysed for total suspended solids (TSS), dry weight, total phosphorus (TP), particulate phosphorus (part$\mathrm{P})$, soluble reactive phosphorus (SRP), total soluble phosphorus (TSP), total Kjeldahl nitrogen (TKN), particulate Kjeldahl nitrogen (part-N), nitrite-nitrogen
$\left(\mathrm{NO}_{2}-\mathrm{N}\right)$, nitrate-nitrogen $\left(\mathrm{NO}_{3}-\mathrm{N}\right)$ and total ammonia nitrogen (TAN).

$\mathrm{NO}_{2}-\mathrm{N}$ and $\mathrm{NO}_{3}-\mathrm{N}$ were analysed photometrically (Merck, 114776/114942). Other physicochemical properties were determined according to standard German methods for the analysis of water, wastewater and sludge, as modified by the International Commission for the Protection of Lake Constance (IGKB 2000).

The efficiency of solid removal was determined from filtration residues according to German standard methods. Performance of the treatment devices was determined by measuring inlet and outlet concentrations for each unit, respectively, and calculating means from these data sets according to the formula:

$$
\mathrm{RE}=\left(\frac{\boldsymbol{C}_{\text {before }}-\boldsymbol{C}_{\text {after }}}{\boldsymbol{C}_{\text {before }}}\right) \times 100
$$

where RE is the removal efficiency $(\%), c_{b e f o r e}$ and $\mathrm{C}_{\text {after }}$ are the concentrations before and after the cleaning unit, respectively.

The TSS profile of the water column was evaluated from samples collected before the surface separator (SP4) and the settling unit (SP3) at 5 different depths: 10, 40, 70, 100, 130 and $155 \mathrm{~cm}$ from the bottom of the tank according to Brinker \& Rösch (2005). The amount of make-up water did not differ statistically between the treatments, which supplied to the system at about $12.82 \pm 3.6 \%$ of total recirculating flow during the control diet phase of the trial and at $14.18 \pm 6.4 \%$ during the cork diet phase $(p>0.05)$.

\section{Measurement of particle size distribution (PSD)}

Water samples for PSD measurements were collected using the sampler described by Brinker \& Rösch (2005) taking water from 3 depths within the water column, at 10,75 and 155 $\mathrm{cm}$ from the bottom of the raceway. The profile was evaluated from samples taken before both extraction points (SP2 and SP4) and the settling unit (SP3), and samples were analysed immediately after collection. Particle size distributions were determined using a noninvasive laser particle sizer (GALAI CIS-1) equipped with a flow controller (GALAI LFC100) and a flow-through cell (GALAI GM-4), as described by Brinker et al. (2005c). The exact sampling protocol is described elsewhere (Brinker et al. 2005a). 


\section{Quantitative removal}

At several time points during the experiment, faeces removed by the surface separator within a $24 \mathrm{~h}$ period were pooled and weighed, and the quantitative efficiency of faeces removal was calculated by the formula:

$$
\begin{aligned}
& \text { Quantitative removal }(\%)= \\
& \left(\frac{\text { Amount of faeces removed }_{\text {day }}(\mathrm{kg})}{\text { Calculated total faeces }_{\text {day }}(\mathrm{kg})}\right) \times 100
\end{aligned}
$$

The total faeces produced per day by fish fed the cork diet were calculated from the wet weight of faeces produced per day, taking into account a dry matter (DM) content of $94 \%$ for the feed $\left(D_{\text {feed }}\right)$ and $18 \%$ for the faeces $\left(\mathrm{DM}_{\text {faeces }}\right)$ and an apparent digestibility coefficient (ADC)-DM of $78 \%$ for the cork diet. The ADC-DM was calculated using the following conservative estimates of digestibility: $90 \%$ for protein, $92 \%$ for fat, $45 \%$ for carbohydrate, $0 \%$ for crude fibre, $0 \%$ for cork, $25 \%$ for ash (J. Holm, BioMar, pers. comm.).

The formula used for DM calculations were as follows:

$$
\frac{\mathrm{DM}_{\mathrm{faeces}}(\mathrm{kg})}{\text { day }}=\frac{\mathrm{DM}_{\text {feed }}(\mathrm{kg})}{\text { day }} \times[1-\operatorname{ADC}(\%)]
$$

\section{Leaching}

Leaching was assessed by comparing TP and total nitrogen with particle bound phosphorus and nitrogen (Brinker et al. 2005b). For the cork trial, floating solids with their distinct higher particulate content were merged with suspended solids from the same trial.

$$
\mathrm{PNC}=\left(\mathrm{PNC}_{1} \times \mathrm{SS}_{1}+\mathrm{PNC}_{2} \times \mathrm{SS}_{2}\right)
$$

where PNC is particulate nutrient content (\%), $\mathrm{PNC}_{1}$ is $\mathrm{PNC}$ before the surface separator, $\mathrm{PNC}_{2}$ is $\mathrm{PNC}$ before the drum filter, $\mathrm{SS}_{1}$ is the solid share in the surface layer, and $\mathrm{SS}_{2}$ is the solid share in the water column.

\section{Statistical analysis}

Data were checked for homoscedasticity using Levene's test (Levene 1960) and normality using visual inspection of distribution followed by a goodness of fit test (Sokal \& Rohlf 1994). Differences in SGR, FCR, TGC, faecal density, TSS load, removal efficiencies and water parameters were tested using $t$-tests and, in the case of un- equal variances, by Welch's test (Welch 1947). For all diet-dependent analyses, the following linear parametric model was applied:

$$
Y_{i j k}=\mu+a_{i}+b_{j}+(a b)_{i j}+\varepsilon_{i j k}
$$

where $Y_{i j k}$ is the evaluated parameter, $\mu$ is the overall mean, $a_{i}$ is diet treatment, $b_{j}$ is fish size, $(a b)_{i j}$ denotes the interaction between the treatments and $\varepsilon_{i j k}$ is the random residual error. Health parameters were tested using a logistic regression on ordinal data.

The coefficient of variation $\left(\mathrm{C}_{\mathrm{V}}\right)$ as a unit for the relative standard deviation was calculated as follows:

$$
\mathrm{C}_{\mathrm{v}}(\%)=\frac{\text { standard deviation }(\sigma)}{\text { arithmetic mean }(\bar{x})} \times 100
$$

Time series means are grand marginal means, derived from a repeated-measures design with time as a random nested block variable (Sachs 1997).

All statistical analyses were performed using JMP (SAS Institute Inc.), version 9.02, and all values are displayed as arithmetic means \pm SE unless otherwise noted.

\section{RESULTS}

Floating faeces were observed within just a few hours of fish feeding on the cork diet (Fig. 4a), and $78.3 \%$ of floating faeces accounting for $35.4 \%$ of total faeces produced were removed by the surface separator and collected in a sludge tank (Fig. 4b). The recovered material had a DM content of $17.7 \pm$ $1.04 \%$, and scanning electron micrographs showed that cork particles remained intact during the entire process of feed pellet extrusion, ingestion, digestion and excretion by fish (Fig. 5).

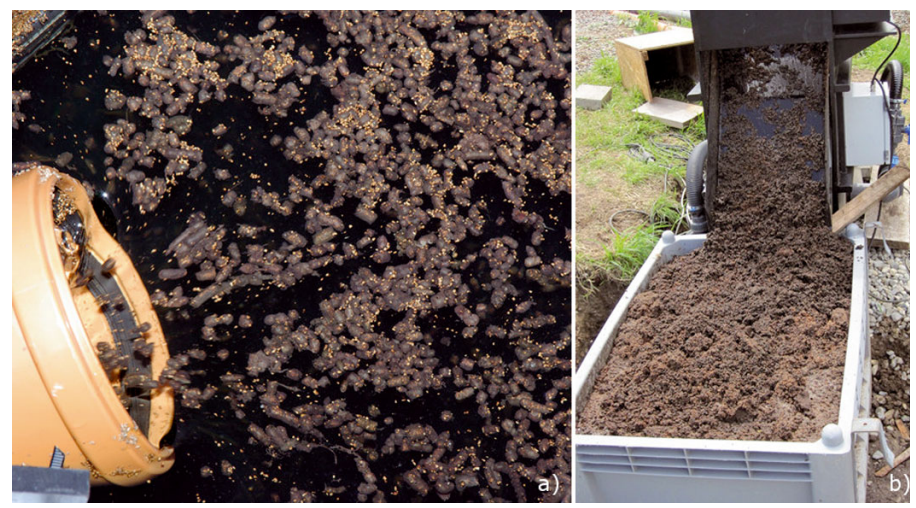

Fig. 4. (a) Floating faeces with cork granulae (lighter, reddish particles) entering the outlet pipe and (b) faeces being collected and transported by the surface separator to a sludge box 


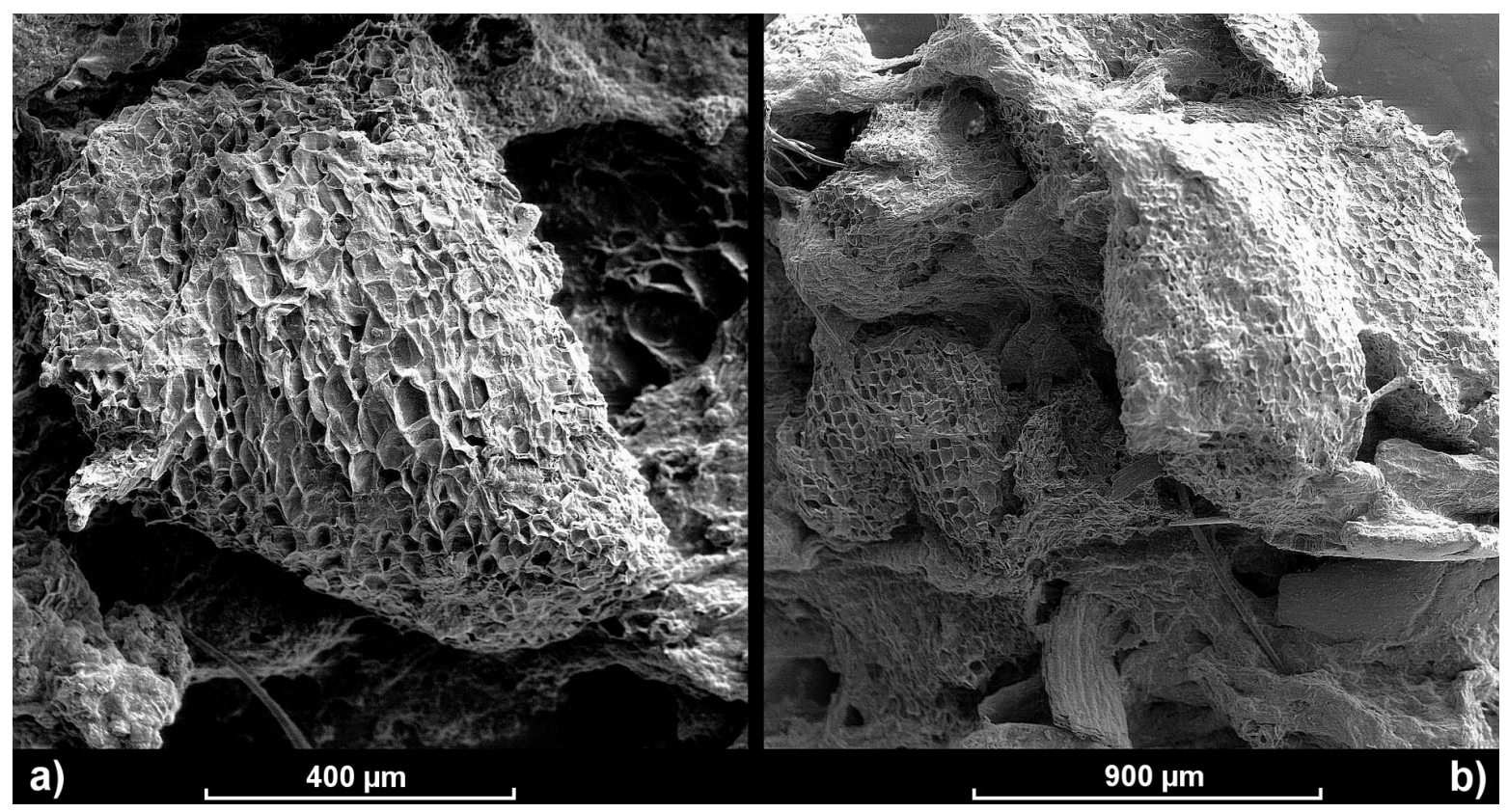

Fig. 5. Scanning electron microscope images of cork Quercus suber granules (a) recovered from the sludge box and (b) embedded in faecal matrix

\section{Experimental diet performance and water parameters}

At the beginning of the cork trial, a few fish were occasionally observed ingesting floating faecal particles, but these were spat out again and not swallowed, as confirmed by examinations of the stomach contents. The behaviour stopped after a few days, and generally both diets were accepted very well. There were no signs of malnutrition or increased mortality. Mean FCRs for whole stock did not differ between the 2 trial phases $(p>0.05)$, with values of $1.02 \pm 0.34$ (mean \pm SD) for the control diet and $0.99 \pm 0.19$ for the cork diet. Thermal growth coefficients (TGC) for fish fed the control and cork diets were $0.18 \pm 0.07$ and $0.17 \pm 0.09$, respectively. No statistical differences between diets were revealed for any of the growth parameters evaluated $(p>0.05)$. Stock biomass was higher during the test period when the cork diet was supplied, and so therefore was the feed demand. The control diet was supplied for $17 \mathrm{~d}$ with $2.45 \mathrm{t}$ feed used, corresponding to $135.9 \mathrm{~kg} \mathrm{~d}^{-1}$. During the cork phase, $4.35 \mathrm{t}$ of feed was supplied over $23 \mathrm{~d}$, corresponding to $155.5 \mathrm{~kg} \mathrm{~d}^{-1}$. Water temperature was $10.6 \pm 1.5^{\circ} \mathrm{C}$ (mean $\pm \mathrm{SD}$ ) during the control phase and $11.2 \pm 1.3^{\circ} \mathrm{C}$ during the cork diet trial. Biofilter temperature was $12.9 \pm 1.1^{\circ} \mathrm{C}$ during the control phase and $12.6 \pm 1.2^{\circ} \mathrm{C}$ during the cork phase. $\mathrm{pH}$ was stable at $7.6 \pm 0.04$ (mean $\pm \mathrm{SD}$ ) throughout the whole trial. The biofilter was completely broken in and operated optimally when the study commenced (P. Störk, Fischzucht Störk, pers. comm.)

\section{Fish health}

According to an independent veterinarian, all fish were in very good overall condition regardless of treatment. No visible lesions or other macroscopic pathologies were reported, and histological assessments were also favourable, with a few exceptions. Four fish from the control group showed an increased number of inflammatory infiltrates (perivascular) in the liver $(p=0.0228)$. No such increase was observed among fish fed the cork diet. However, 3 out of 19 cork-fed fish did show significant increased single cell losses in the liver $(p=0.0289)$ compared to 1 fish in the control group. According to the official veterinary examiner of the fish health service (STUA Diagnostikzentrum, Aulendorf, Germany), such liver anomalies are in line with expectations for healthy fish with comparable husbandry, especially larger individuals, and 'a connection of the isolated single cell losses with the incorporated additive is highly unlikely' (U. Rucker pers. comm.).

\section{Faecal density}

In order for a particle to float, density must be lower than $\sim 1 \mathrm{~g} \mathrm{~cm}^{-3}(\approx$ density of fresh water). This was achieved by the addition of $2.5 \%$ cork to the feed, and altogether faeces from fish fed the cork diet $\left(0.998 \pm 0.008 \mathrm{~g} \mathrm{~cm}^{-3}\right)$ exhibited significantly lower 
Table 4. Density $\left(\mathrm{g} \mathrm{cm}^{-3}\right)$ of intestinal faeces from rainbow trout Oncorhynchus mykiss and faeces allowed to soak in system water for $1 \mathrm{~h}$. Values are means $\pm \mathrm{SE}$. Values marked with asterisks are significantly lower than the respective value of the control diet $\left({ }^{* *} \mathrm{p}<0.0001 ;{ }^{* *} \mathrm{p}<0.01\right)$. na: not applicable

\begin{tabular}{|lcccccc}
\hline & \multicolumn{2}{c}{$\begin{array}{c}\text { Portion-sized fish }(>150 \mathrm{~g}) \\
(\mathrm{n}=46)\end{array}$} & \multicolumn{2}{c|}{$\begin{array}{c}\text { Small fish }(<150 \mathrm{~g}) \\
(\mathrm{n}=26)\end{array}$} & $\begin{array}{c}\text { Surface separator } \\
(\mathrm{n}=8)\end{array}$ \\
\hline Diet & Soaked & Intestinal & Soaked & Intestinal & na \\
\hline Control & $1.032 \pm 0.002$ & $1.049 \pm 0.001$ & $1.023 \pm 0.004$ & $1.028 \pm 0.002$ & $0.961 \pm 0.002$ \\
\hline Cork & $0.995 \pm 0.002^{* * *}$ & $1.003 \pm 0.002^{* * *}$ & $0.995 \pm 0.002^{* * *}$ & $1.001 \pm 0.004^{* *}$ & \\
\hline
\end{tabular}

density values than those from fish fed the control $\operatorname{diet}\left(1.034 \pm 0.012 \mathrm{~g} \mathrm{~cm}^{-3} ; \mathrm{p}<0.0001\right.$; Table 4). Floating faecal particles recovered by the surface separator were significantly less dense $(p<0.0001)$ than intestinal faeces generated by the control diet, at $0.961 \pm 0.002$ to $1.049 \pm 0.001 \mathrm{~g} \mathrm{~cm}^{-3}$, respectively (Table 4). Soaking of the control faeces from small fish to simulate retention in a real farming situation did not yield a significant reduction of density $(\mathrm{p}>$ $0.05)$; however, the faeces from portion-sized (>150 g) fish did become less dense with soaking time $(p<$ 0.02). Despite this disparity, the factor 'fish size' had no significant effect on the density for stock fed with the cork diet $(p>0.05)$.

\section{Influence of cork on water parameters}

$$
\text { TSS - profile measurement }
$$

The cork diet generated intact and floating faecal pellets. Between 62 and $76 \%$ of total TSS load was

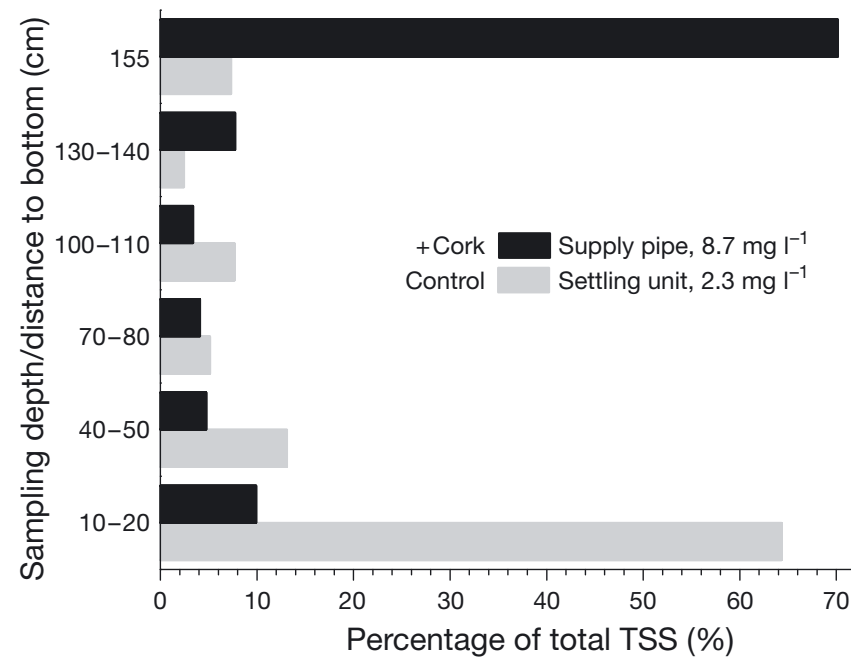

Fig. 6. Vertical profile of total suspended solids (TSS) load for the 2 diets before removal $(n=238)$. The surface separator was engaged during the cork trial; the settling basin operated during the control trial concentrated in surface film (Fig. 6), while $64 \%$ of faeces generated by the control diet accumulated within 10 to $20 \mathrm{~cm}$ of the raceway bottom (Fig. 6). For both diets, the remainder of TSS load was distributed evenly throughout the water column (Fig. 6). The water flow quickly transported floating faeces to the surface separator via the 2 outlet pipes, and faecal material was only rarely observed moving along the raceway bottom. Total TSS concentration over the whole water column was considerably higher during the cork phase of the trial, at $8.7 \mathrm{mg} \mathrm{l}^{-1}$ compared to $2.3 \mathrm{mg} \mathrm{l}^{-1}$ in the control phase.

\section{TSS - single pass removal efficiency}

The drum filter operated more effectively when equipped with the $30 \mu \mathrm{m}$ gauze than with the $100 \mu \mathrm{m}$ gauze for both diets $(p=0.0013$; Fig. 7). Furthermore, removal efficiency was significantly higher during the

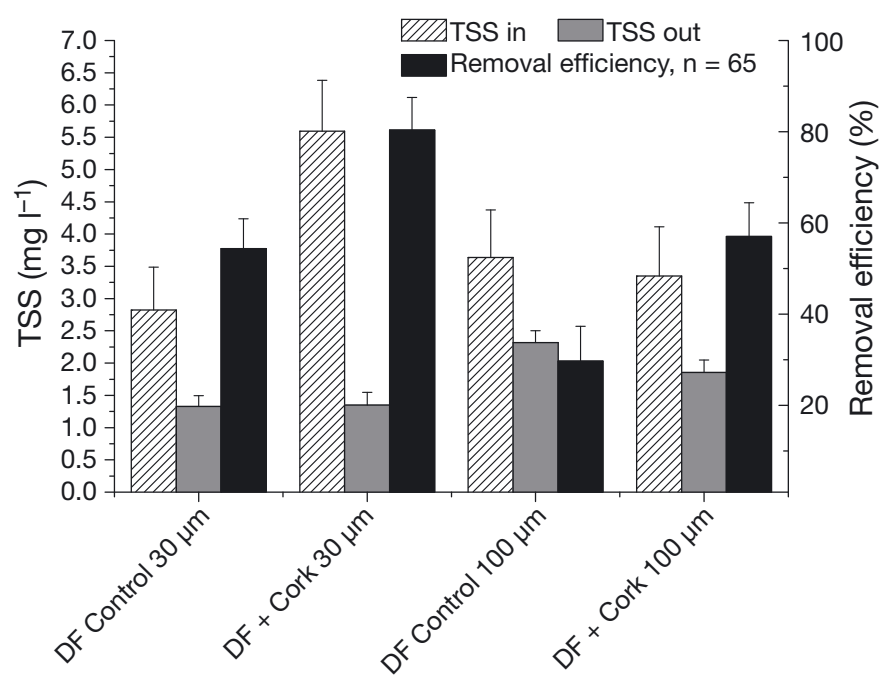

Fig. 7. Merged total suspended solids (TSS) concentration (left y-axis) and removal efficiency (right y-axis) of the drum filter (DF) (measured at sampling points SP7 and SP8, see Fig. 1) equipped with a 30 or $100 \mu \mathrm{m}$ gauze. Values are means \pm SE. For significant differences, see 'Results' 
Table 5. Total suspended solids concentration (TSS, $\mathrm{mg} \mathrm{l}^{-1}$ ) before and after the settling basin (control diet; sampling points SP3 and SP4, see Fig. 1) and surface separator outlet pipes (cork diet; SP2/SP4 and SP5, see Fig. 1) and associated removal efficiency (RE). Values are means \pm SE. Values marked with asterisks are significantly different from the respective value of the control diet $\left({ }^{* * *} \mathrm{p}<0.0001,{ }^{*} \mathrm{p}<0.05\right)$. na: not applicable, as these were unfiltered counterparts remaining in the water column

\begin{tabular}{lccc} 
Distance to bottom $(\mathrm{cm})$ & TSS in & TSS out & RE (\%) \\
\hline Control & $\mathbf{( n = 2 5 )}$ & $\mathbf{( n = 3 0 )}$ & \\
10 (bottom) & $11.9 \pm 0.6$ & $5.0 \pm 0.2$ & 58.0 \\
75 (mean water) & $5.0 \pm 0.1$ & $3.6 \pm 0.1$ & 28.0 \\
155 (surface) & $4.2 \pm 0.1$ & $3.9 \pm 0.1$ & 7.2 \\
Average & $7.0 \pm 0.5$ & $4.2 \pm 0.1$ & $40.0^{*}$ \\
+Cork & $(\mathbf{n = 4 7 )}$ & $\mathbf{( n = 8 )}$ & \\
10 (bottom) & $2.3 \pm 0.1^{* * *}$ & na & \\
75 (mean water) & $2.6 \pm 0.1^{* * *}$ & na & \\
155 (surface) & $31.1 \pm 0.6^{* * *}$ & $2.9 \pm 0.1$ & \\
Average & $12.0 \pm 0.6^{* * *}$ & $2.6 \pm 0.1^{*}$ & $78.3^{*}$ \\
\hline
\end{tabular}

cork trial. Removal efficiency with the $30 \mu \mathrm{m}$ gauze during the cork phase of the trial was $80.2 \pm 7.2 \%$ and $53.9 \pm 6.6 \%$ for the control phase $(\mathrm{p}=0.009)$. Removal efficiency with the $100 \mu \mathrm{m}$ gauze dropped to $56.6 \pm$ $7.5 \%$ for the cork diet and $29.0 \pm 7.7 \%(p=0.0122)$ for the control. Significantly higher removal efficiency was achieved by the surface separator than the settling basin, with $78.3 \%$ compared to $40 \%$ (Table 5).

\section{Biofilter performance - TAN}

Application of the cork diet had a significant effect on TAN levels in the production unit $(p<0.0001)$,

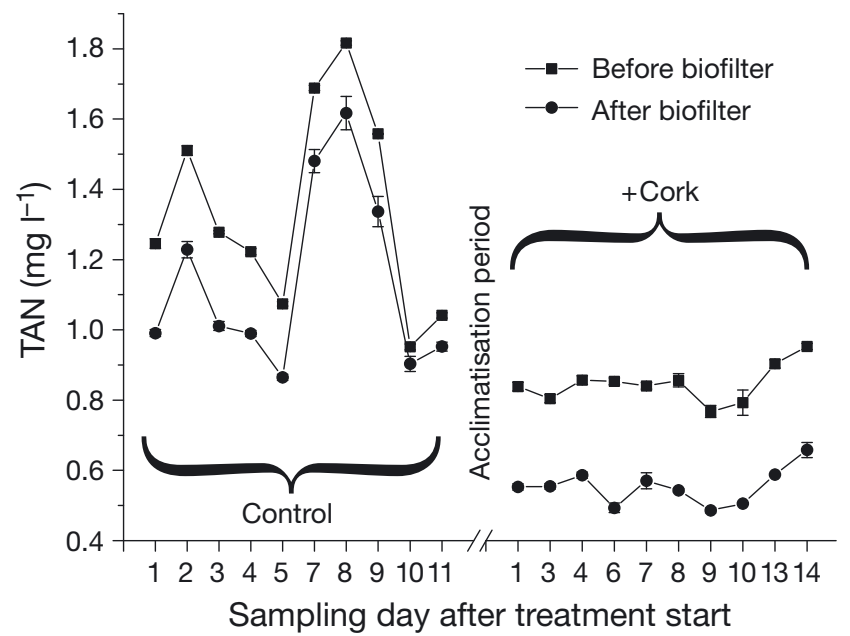

Fig. 8. Timeline of total ammonia nitrogen (TAN) during the trial, measured for both diets before and after the biofilter $(\mathrm{n}=160)$. Values are means $\pm \mathrm{SE}$ and biofilter performance was distinctly more stable and robust during this phase of the trial (Fig. 8), as reflected by the $\mathrm{C}_{\mathrm{V}}$. During the control phase, TAN levels were unstable and ranged from $0.864 \pm 0.022$ to $1.816 \pm 0.017 \mathrm{mg} \mathrm{l}^{-1}\left(\mathrm{C}_{\mathrm{V}}=24.8 \%\right)$. Distinctly lower TAN levels and reduced variation were observed during the cork phase of the trial, when values varied between $0.486 \pm 0.007$ and $0.952 \pm 0.007 \mathrm{mg} \mathrm{l}^{-1}\left(\mathrm{C}_{\mathrm{V}}=\right.$ $7.8 \%) . \mathrm{C}_{\mathrm{V}}$ was significantly lower during the cork phase $(\mathrm{p}=0.0384)$.

TAN levels measured at the inlet of the production system were $\sim 50 \%$ lower while fish were fed the cork diet, at $0.475 \pm 0.028 \mathrm{mg} \mathrm{l}^{-1}$ compared to 0.951 $\pm 0.027 \mathrm{mg} \mathrm{l}^{-1}$ during the control phase $(\mathrm{p}<0.0001$; Fig. 9). TAN levels measured at the inlet and the outlet of the biofilter were also significantly lower during the cork phase at $0.847 \pm 0.033$ and $0.554 \pm$ $0.035 \mathrm{mg} \mathrm{l}^{-1}$, respectively, compared to $1.339 \pm$ 0.032 and $1.098 \pm 0.034 \mathrm{mg} \mathrm{l}^{-1}$, respectively, during the control phase. Removal efficiencies were significantly higher during the cork phase than the control phase, at $34.6 \pm 0.8 \%$ and $18.9 \pm 0.8 \%$, respectively $(\mathrm{p}<0.0001)$.

Biofilter performance was also evaluated, and values corrected according to respective influent loads. The corrected TAN concentrations entering the biofilter were comparable for both phases of the experiment. However, effluent values corrected for influent load for the biofilter were significantly lower during the cork phase, at $0.079 \pm 0.009 \mathrm{mg} \mathrm{l}^{-1}$ compared to $0.147 \pm 0.009 \mathrm{mg} \mathrm{l}^{-1}$ for the control, corresponding to a TAN removal efficiency of $78.9 \%$ during the cork phase compared to $63.3 \%$ for the control phase ( $p<$ 0.0001).

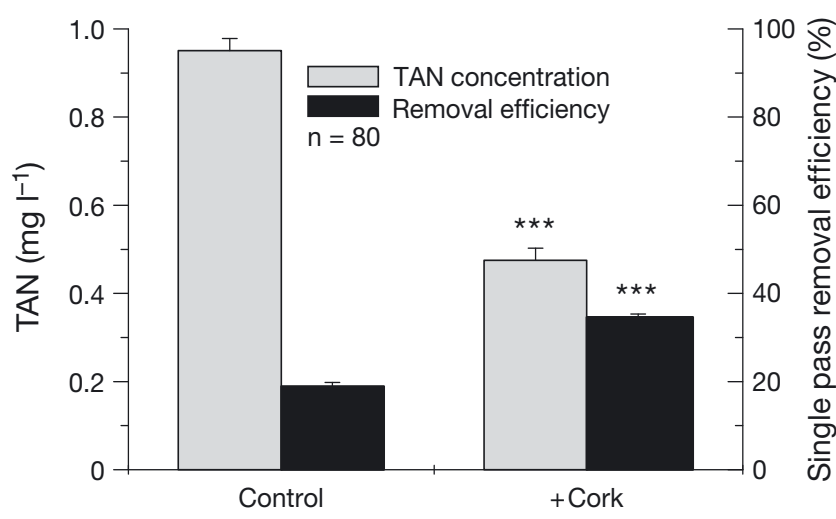

Fig. 9. Total ammonia nitrogen (TAN) and single pass removal efficiencies during the control diet and cork diet phases of the experiment. Bars marked with asterisks are significantly different from the control $(p<0.0001)$. Values are means $\pm \mathrm{SE}$ 


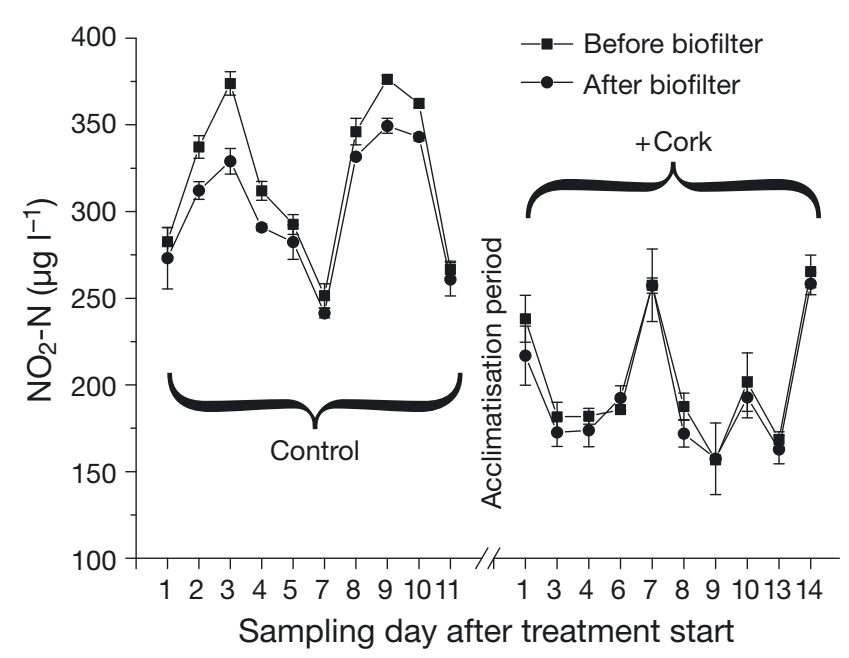

Fig. 10. Timeline of nitrite levels during the trials, measured before and after the biofilter for both diets $(n=80)$. Values are means $\pm \mathrm{SE}$

$$
\text { Biofilter performance }-\mathrm{NO}_{2}-\mathrm{N}
$$

The diet had a significant effect on nitrite levels in production water $(\mathrm{p}<0.0001)$. During the control phase of the trial, nitrite levels ranged from $241.4 \pm 3$ to $376.3 \pm 2 \mu \mathrm{g} \mathrm{l}^{-1}\left(\mathrm{C}_{\mathrm{V}}=13.1 \%\right)$. Distinctly lower values ranging from $156.7 \pm 0.0001$ to $265.5 \pm 9 \mu \mathrm{g} \mathrm{l^{-1 }}$ $\left(C_{V}=19.1 \%\right.$; Fig. 10) were observed when the cork diet was fed $(\mathrm{p}=0.0001) . \mathrm{C}_{\mathrm{V}}$ was significantly lower during the control phase $(\mathrm{p}=0.0198)$.

During the cork trial, nitrite levels in the inlet water were $185.6 \pm 9.1 \mu \mathrm{g} \mathrm{l}^{-1}$, significantly lower than the $290.5 \pm 7.0 \mu \mathrm{g} \mathrm{l}^{-1}(\mathrm{p}<0.0001)$ recorded in the control phase. $\mathrm{NO}_{2}-\mathrm{N}$ levels measured at the inlet and outlet of the biofilter were also significantly lower for the cork diet, at $202.3 \pm 8.6$ and $196.95 \pm 8.4 \mu \mathrm{g} \mathrm{l} \mathrm{l}^{-1}$, respectively, compared with $301.4 \pm 8.3$ and $320.1 \pm$ $9.9 \mu \mathrm{g} \mathrm{l}^{-1}$, respectively, for the control diet $(\mathrm{p}<$ 0.0001). Removal efficiency was significantly improved during the cork trial, at $3.58 \pm 1.09 \%$ compared with an accumulation of nitrite in the production water observed during the control phase, when levels rose by $6.04 \pm 1.06 \%(p<0.0001$; Fig. 11).

\section{Phosphorus}

TP measured at the system inlet was significantly lower during the cork phase of the trial, at $182.0 \pm 2.2$ $\mu \mathrm{g} \mathrm{l^{-1 }}$ compared to $226.5 \pm 2.4 \mu \mathrm{g} \mathrm{l^{-1 }}$ during the control phase ( $p<0.0001$; Fig. 12). TSP concentrations measured at the inlet were also significantly reduced when the cork diet was fed, at $183.2 \pm 2.2 \mu \mathrm{g} \mathrm{l}^{-1}$ compared to $226.3 \pm 2.3 \mu \mathrm{g} \mathrm{l}^{-1}$ for the control diet $(\mathrm{p}<0.0001)$. Ac-

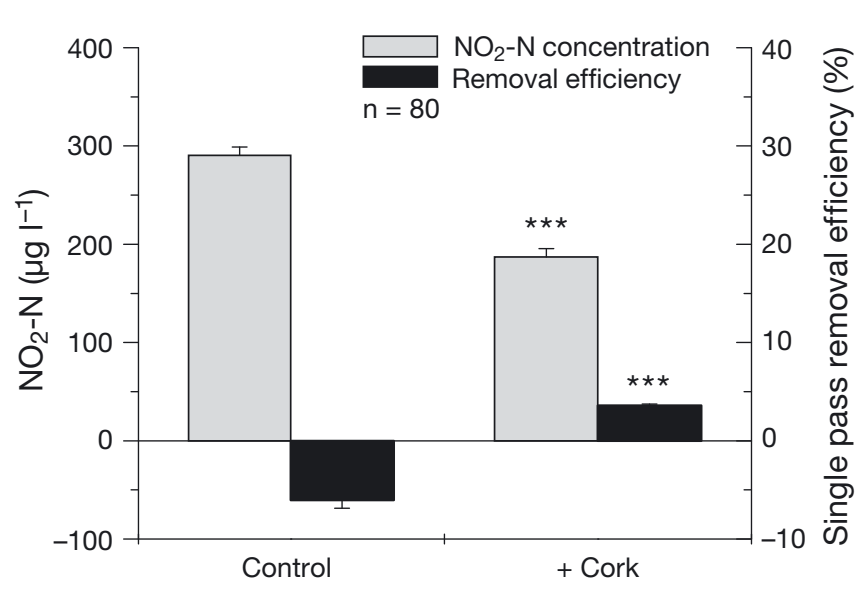

Fig. 11. Nitrite levels and single pass removal efficiencies during the control diet and cork diet phases of the trial. Bars marked with asterisks differ significantly from the control $(p<0.0001)$. Values are means \pm SE

cordingly, SRP was also significantly lower in the cork phase, at $135.8 \pm 1.5 \mu \mathrm{g} \mathrm{l}^{-1}$ compared to $168.7 \pm 1.8 \mu \mathrm{g}$ $1^{-1}$ for the control phase $(\mathrm{p}<0.0001)$.

\section{Leaching}

DM levels of part- $\mathrm{N}$ and part-P in the water were consistently reduced when the cork diet was fed. The large cork diet solids removed by the surface separator had a phosphorus content of $26.8 \pm 2.3 \%$, whereas the solids removed by the drum filter had a phosphorus content of $10.3 \pm 1.8 \%$. Suspended solids from the control diet collected by the drum filter con-

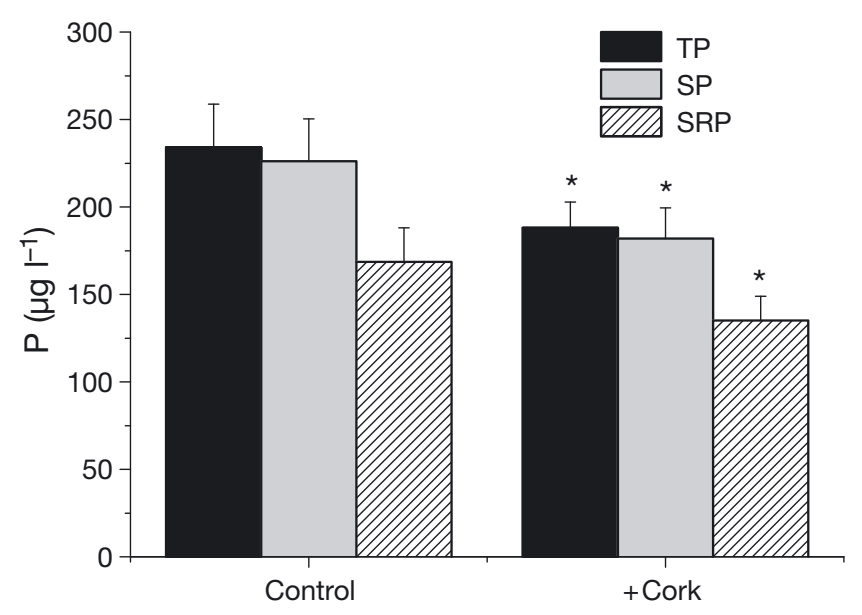

Fig. 12. Total phosphorus (TP), total soluble phosphorus (SP) and soluble reactive phosphorus ( $\mathrm{SRP} ; \mathrm{PO}_{4}$ ) measured at the system inlet. Bars marked with asterisks differ significantly from the control $(p<0.05)$. Values are mean \pm SD 


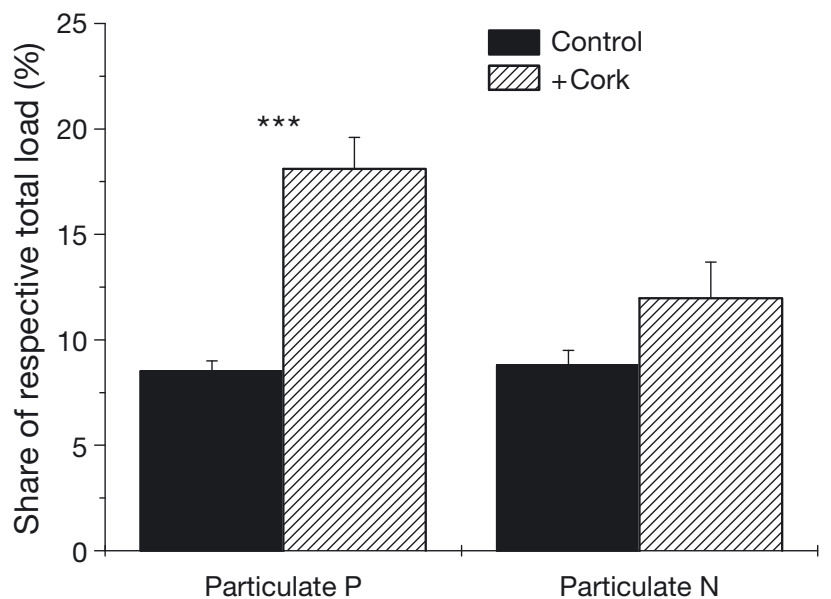

Fig. 13. Percentage of particulate phosphorus and nitrogen contributing to total loads under different dietary treatments. Values are mean $\pm \mathrm{SE}$

tained $8.7 \pm 1.6 \%$ phosphorus, indicating that cork treatment had a significant effect on phosphorus retention $(p<0.0001)$. A similar pattern was found for part- $\mathrm{N}_{\text {; }}$ solids removed by the surface separator had a relatively high nitrogen content of $16.9 \pm 1.5 \%$ compared to those removed by the drum filter, in which the nitrogen content was $9.6 \pm 1.4 \%$. Suspended solids from the control diet collected by the drum filter contained $9.2 \pm 1.7 \%$ part-N. Taking into account the percentage of faeces removed by the surface separator, addition of cork more than doubled the amount of phosphorus that remained bound in particulate waste from $8.5 \pm 0.5 \%$ (mean $\pm \mathrm{SE}$ ) to
$18.1 \pm 1.5 \%(p<0.0001 ;$ Fig. 13). The proportion of particle-bound nitrogen also increased, from $8.8 \pm$ $0.7 \%$ to $12.0 \pm 1.7 \%$ as a result of cork supplementation, although in this case the improvement was not statistically significant $(p=0.0907)$.

\section{Particle size distribution}

PSDs of the solid waste at SP3 at different depths in the vertical profile of the water column and during different phases of the dietary trial are shown in Fig. 14. Sampling depth $(p<0.0001)$ and diet $(p<$ 0.0115 ) both had a significant effect on PSD. The cork treatment led to an increased proportion of larger particles, especially at the surface, with smaller particles dominating at middle depths and larger ones near the bottom, whereas during the control phase of the trial, particle size correlated positively with water depth. In an accumulative view, Table 6 shows the PSD-derived percentage of cumulative particle volume of particles smaller than 30, 100 and $600 \mu \mathrm{m}$ at 3 different sampling depths.

\section{DISCUSSION}

The shift of solid load from the water column to the surface stream achieved in this study and the effective performance of the surface separator in removing an average of $78.3 \%$ surface waste resulted in an overall improvement in system efficiency. Fish

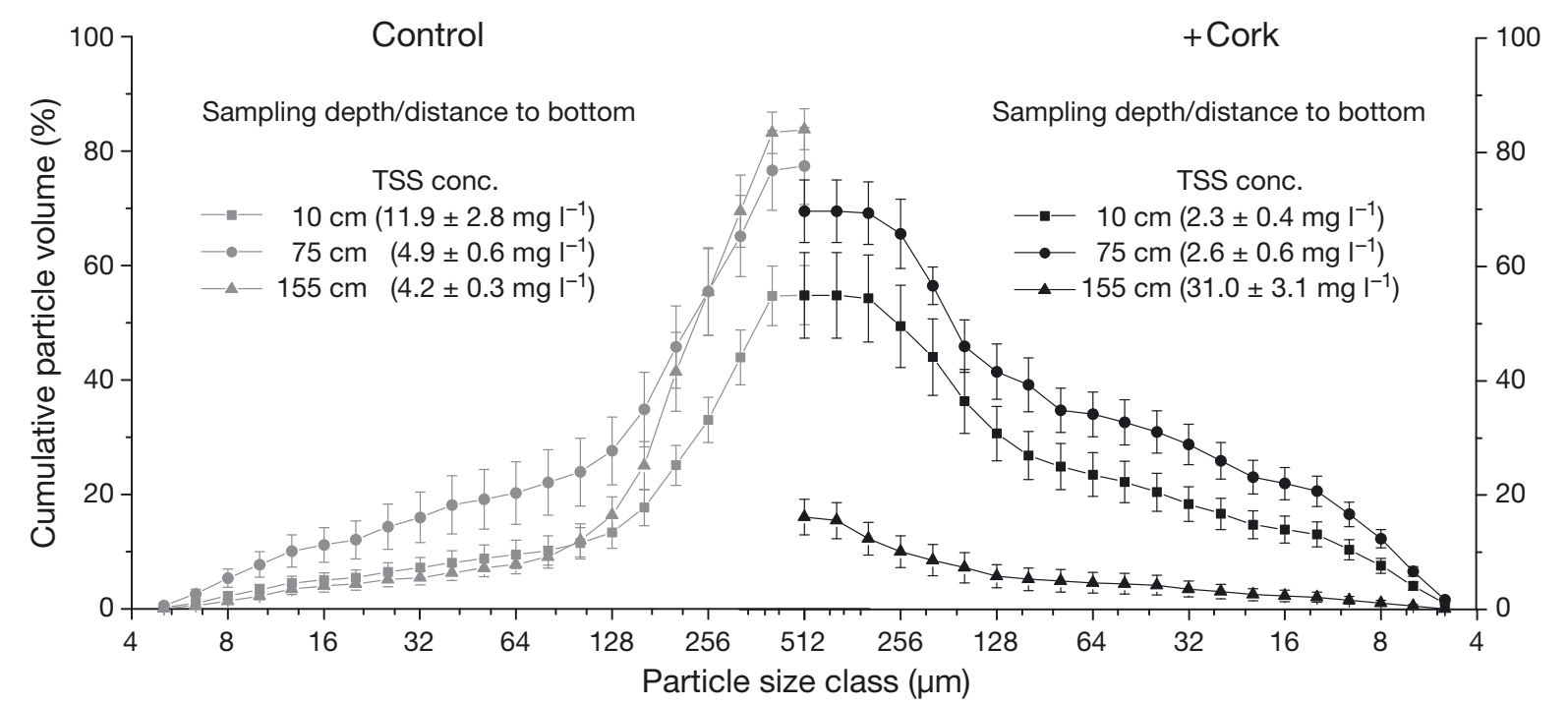

Fig. 14. Volume-dependent cumulative size distributions for suspended particles collected during the cork and control phases of the diet trial. Values are mean $\pm \mathrm{SE}$. Water depths from the tank bottom of sampling points with the respective total suspended solids (TSS) concentrations (in brackets) are given 
Table 6. Cumulative percentages of total suspended solids (TSS) volume represented by particles smaller than 30, 100 and $600 \mu \mathrm{m}$ originating from the different dietary treatments measured at 3 water depths $(n=104)$. Values are means \pm SE. Means with asterisks are significantly different from the control $\left({ }^{* * *} \mathrm{p}<0.0001,{ }^{* *} \mathrm{p}<0.01,{ }^{*} \mathrm{p}<0.05\right)$

\begin{tabular}{|lrrrr|}
\hline \multirow{2}{*}{$\begin{array}{l}\text { Distance to } \\
\text { bottom }(\mathrm{cm})\end{array}$} & $\begin{array}{c}\text { TSS total } \\
\left(\mathrm{mg} \mathrm{l}^{-1}\right)\end{array}$ & $<30 \mu \mathrm{m}$ & $<100 \mu \mathrm{m}$ & $<600 \mu \mathrm{m}$ \\
\cline { 3 - 5 } Control & & & & \\
10 & $11.9 \pm 2.8$ & $7.2 \pm 1.8$ & $11.5 \pm 2.7$ & $54.8 \pm 5.2$ \\
75 & $5.0 \pm 0.6$ & $16.0 \pm 4.4$ & $23.9 \pm 5.9$ & $77.4 \pm 6.7$ \\
155 & $4.2 \pm 0.3$ & $5.4 \pm 1.2$ & $12.0 \pm 2.9$ & $83.8 \pm 3.5$ \\
+ Cork & & & & \\
10 & $2.3 \pm 0.4^{* *}$ & $18.4 \pm 3.0^{* *}$ & $26.9 \pm 4.2^{* *}$ & $54.9 \pm 7.5$ \\
75 & $2.6 \pm 0.3^{* *}$ & $28.9 \pm 3.5^{*}$ & $39.3 \pm 4.7^{*}$ & $69.7 \pm 5.5$ \\
155 & $31.0 \pm 3.1^{* * *}$ & $2.3 \pm 0.6^{*}$ & $3.5 \pm 0.9^{*}$ & $12.3 \pm 1.7^{* * *}$ \\
\hline
\end{tabular}

learned quickly not to mistake floating faeces for food, and feed utilization and temperature-corrected growth were not affected by the inclusion of $2.5 \%$ cork. This is somewhat surprising, since the addition of even small amounts of indigestible material to feed might be expected to have a nutrient diluting effect. However this negative effect seems to be compensated in the present case by improved water quality. Reduced levels of TAN and nitrite and a lower load of fine particles led to a better performance of fish stock, a possible response to the reduced stress burden related to water quality (cf. details below). The positive husbandry effects are especially remarkable given that the increased feeding during the cork phase inevitably resulted in increased excretion. The unaffected survival figures and the results of liver and intestine assays indicate that negative health effects of cork treatment are unlikely.

During the cork treatment, quantitative measurements of the skimmed waste indicated that about $35.4 \%$ of total faeces produced were removed from the system. The speed and quantity of this direct removal had tremendous effects on water quality, as discussed below.

Production of TAN in the rearing compartments was considerably elevated during the cork treatment, due to the increased demand for food of the larger standing stock. However, the TAN removal efficiency of the single-pass biofilter was increased by $\sim 16 \%$ over the same period, resulting in an overall halving of TAN levels at the system inlet. Furthermore, biofilter performance was distinctly more stable and robust, resulting in lower levels of TAN throughout the study period. $\mathrm{NO}_{2}-\mathrm{N}$ status changed accordingly, from net production during the control phase (indicating biofilter overload) to a net reduc- tion during the cork phase. In most recirculating systems, stocking capacity for trout is limited by TAN levels $>1 \mathrm{mg} \mathrm{l}^{-1}$. Under the conditions recorded during the cork trial, stocking levels in the study farm might be increased by $\sim 50 \%$, while still maintaining water quality. Table 7 gives an overview of the biofilter efficiencies under each of the 2 dietary treatments.

The considerable improvement in biofilter efficiency during the cork trial can only be explained by lower organic and solid load in the recirculation loop, reducing clogging of the filter and, most importantly, limiting the resources available to heterotrophic bacteria and thereby making room for necessary nitrogenous bacteria (Ling \& Chen 2005, Michaud et al. 2006).

Aquacultural waste loads are exposed to turbulence and shear forces induced by pumps and fish motion etc., which result in disintegration of the faecal casts (McMillan et al. 2003). Floating faeces, however, are immediately and gently transported via the surface stream to the removal device, encountering much less exposure to turbulences and shear than particles distributed in the water column or near the bottom. The PSD measurements in this study confirm that the faecal waste produced by fish fed the cork diet contained an increased percentage of large particles. The lower surface area to volume ratios of large particles and the short exposure times of floating faeces both led to reduced leaching and an increased proportion of nitrogen and phosphorus being retained within the particulate fraction and thus ultimately removable by mechanical means (Brinker et al. 2005a). In this study, the rapid removal of $35 \%$ of total solid production as floating faeces with a high proportion of particle-bound waste and negligible microbial degradation minimized phosphorus and nitrogen input at the start of the recirculation loop throughout the cork trial.

Table 7. Summary of single-pass biofilter efficiencies and removal rates for nitrite-nitrogen $\left(\mathrm{NO}_{2}-\mathrm{N}\right)$, total nitrogen (TN) and total ammonia nitrogen (TAN). Values are means \pm SE. na: not applicable

\begin{tabular}{|c|c|c|c|c|}
\hline & \multicolumn{2}{|c|}{ Reduction (in \%) } & \multicolumn{2}{|c|}{ Removal rate $\left(\mathrm{g} \mathrm{d}^{-1} \mathrm{~m}^{-2}\right)$} \\
\hline & Control & + Cork & Control & + Cork \\
\hline $\mathrm{NO}_{2}-\mathrm{N}$ & $-6.0 \pm 1.1$ & $3.6 \pm 1.1$ & na & 0.0024 \\
\hline TN & $20.2 \pm 1.3$ & $38.2 \pm 1.2$ & 0.007 & 0.069 \\
\hline TAN & $18.9 \pm 0.9$ & $34.6 \pm 0.9$ & 0.038 & 0.064 \\
\hline
\end{tabular}


Minimizing the exposure of faeces to turbulence and shear also resulted in fewer fine particulates (below 30 or $100 \mu \mathrm{m}$ ) being generated during the cork trial. Fine particles can reduce biofilter efficiency by clogging (Muir \& Roberts 1982), thus leading indirectly to deteriorating water quality, and they can also affect fish performance, health, and welfare, e.g. by causing gill irritation leading to reduced resistance to disease (Wickens 1981, Gregory \& Grandin 2007).

The accumulation of fine solids is a particular problem in RAS (Timmons et al. 2002), and an important limiting factor on system performance. The distinct improvements in biofilter efficiency seen in this study, and the surprisingly good utilization of the cork feed are thus likely to be linked to the superior husbandry environment permitted by the reduced formation of fine particles. The favourable PSD profiles observed during the cork trial, with much lower percentages of fine particles and increased proportions of large particles, also led to improved performance of the drum filter. Overall, the single-pass removal efficiency of the experimental unit was in the normal range for recirculating systems (Davidson $\&$ Summerfelt 2005) and reflected the significance of small particle sizes usually found in RAS. Solid concentrations recorded entering the drum filter did not differ significantly between the dietary treatments, but these results reflect a bias in the experimental system. Water for treatment by the drum filter was collected by suction via a thick tube with multiple inlet holes designed to draw water from the entire water column. However, in the course of the trial it became obvious that the collection of floating faeces at the top hole was hampered by suction loss due to air contact. Thus floating particles were discriminated against in the exact place where they were most prevalent in the cork trial. The removal efficiency of a permanent drum filter that did not rely on suction sieving would have been distinctly higher.

During the cork trial, TSS loads recorded across the entire water column, including the surface film, were almost 4 times higher than in the control. This significant disparity is due to 3 factors: (1) faecal particles generated by the cork diet were abundantly present at the water surface, whereas much of the faecal material generated by the control diet settled or hovered close to $(<10 \mathrm{~cm})$ the raceway bottom, where it escaped measurement; (2) solid production was higher during the cork trial due to increased demand for feed and larger standing stock; (3) a significant proportion of solids generated in the control treatment were lost to dissolution, leaching and microbial degradation (Dalsgaard \& Pedersen 2011). These are all factors likely to become significant benefits when a drum filter is engaged, as smaller losses and larger particles will clearly increase removal potential.

However, the application of a surface separator has several advantages such as its simplicity and costeffectiveness, as only the upper $(1-2 \mathrm{~cm})$ layer of water has to be treated. Surveys conducted on the energy consumption showed that the use of the surface separator in continuous operation amounts to only $14.7 \%$ of the energy consumption of an appropriately dimensioned drum filter for this system with $1410 \mathrm{kWh} \mathrm{yr}^{-1}$ for the surface separator compared to $9570 \mathrm{kWh} \mathrm{yr}^{-1}$ for the drum filter.

Moreover, the production of sludge with $>18 \%$ DM and high retention of phosphorus and nitrogen in the particles (Chen et al. 2003) is a significant benefit when a surface separator is used. The usual DM content of backwash sludge is in the range of 0.1 to $0.2 \%$ (van Rijn 2013), and reducing such sludge volume in order to limit transportation and storage costs and disposal fees, is itself a time-, energy- and cost-consuming exercise (Martins et al. 2010, Badiola et al. 2012). The surface separator, however, combines effluent treatment and efficient sludge processing, rendering further dewatering and drying unnecessary. The sludge may be directly up-valued as a fertilizer, composted or transported cost-effectively for off-site disposal. Furthermore, since cork is a natural product, it poses no problems regarding disposal, and may even add value to fertilizer, as cork granules are known to loosen soil and provide aeration and are already used for this purpose in industrial-scale greenhouses (D. Zimmermann, Amorim, pers. comm.).

Despite being at an early stage of experimental development, the surface separator was highly efficient in treating the surface flow. However, since in the real farming situation, a significant proportion of the solid waste did not float before entering the supply pipes and consequently was not removable by the surface separator, there was a considerably disparity between the potential removal efficiency of the separator $(78.3 \%$ of TSS in the surface stream) and the efficiency achieved for the system as a whole (35\% of TSS production). Lab studies (M. Schumann et al. unpubl.) indicate that floating faeces maintain positive buoyancy for hours, so reasons for the substantial proportion of non-floating material can be attributed mainly to on-site conditions on the farm. As a standard semi-recirculating, working farm it was not set up to take advantages of floating faeces. Nevertheless, the problems can be easily identified and addressed. One important issue is the use of sur- 
face aerators, which cause uncontrolled disintegration of floating fecal particles and dissociation of cork particles. Thus the density of remaining material increases and previously floating particles drop into suspension lower in the water column. Furthermore, wind exposure and areas of dead water in the raceway turns led to a disproportionate accumulation of faeces in certain areas of the system. Prolonged residence time leads to further dissociation of cork granules. In the context of the study farm, the use of alternative aeration systems such as U-Tube aeration (Timmons et al. 2002) or jet aeration, windscreens and rounded corners in the turns would easily remedy these problems and would significantly increase solid waste removal potential.

While these results are promising, the dietary cork approach still has potential for refinement. It is obvious from the density data that cork treatment was less effective when applied to small fish (62-177 g) than large fish (178-891 g), with a higher percentage of small fish faecal casts observed in suspension rather than floating. A likely reason is less effective retention of cork granules in the matrix of small faecal casts due to a higher surface to volume ratio, which facilitates the separation of cork granules from the pellet and makes them increasingly susceptible to disruption by surface turbulence as described above. This problem might be overcome by a slightly increased level of cork inclusion, or use of smaller cork granules.

A further matter for consideration is the patchy spatial distribution of cork granules within the faeces, and the heterogeneous nature of the cork granules themselves, which vary naturally in terms of density. Granules derived from thick phloem rings or ligneous tissues have a higher density than those from other parts of the cork oak cambium (Unger \& Brinker 2013b). This problem could be reduced by decreasing cork granule size and narrowing the size range. Such cork optimization is technically feasible (D. Zimmermann, Amorim, pers. comm.).

The overall cork cost is about $€ 60 \mathrm{t}^{-1}$ fish feed for the current market price and the inclusion level considered in this study. Currently there are about $3000 \mathrm{t}$ of cork available, enough to produce over $100000 \mathrm{t}$ of feed which can be increased with a rising demand. The cost could be further reduced by using more effective cork granules with an optimized density structure and size range in order to minimize inclusion levels, and the price of the raw material could be lowered by an increasing demand (D. Zimmermann, Amorim, pers. comm.)

The floating faeces approach is suitable for recirculating systems, where the cost-effective management of particulates is an issue of key importance (Badiola et al. 2012). However, another promising application might be in ponds and net-cages, where the accumulation and degradation of aquacultural waste initiates geochemical effects that impact the macrobenthic environment.

\section{CONCLUSIONS}

The optimized removal of faeces from the surface stream improves diverse aspects of system performance, including water quality, efficiency of filter systems, fish growth and welfare. The application of the cork diet lowered nutrient load of the system water and therefore potential emissions despite stocking densities of fish being higher during the experimental treatment than during the control. System evaluations and fish performance, plus favourable pathological assessments indicate that cork supplementation did not impact fish in terms of feed utilization or health. The very high DM content of faecal sludge recovered by the surface separator means that no further processing is required, and because cork is a natural biological material, the sludge can be up-valued directly for use as fertilizer.

Acknowledgements. We are very grateful to the following individuals: Peter Störk for providing parts of his fish farm for the study and the Störk family for supporting us during the whole experiment; Andreas Zordel for technical assistance; Andreas Zordel, Hannes Strubelt and Michael Rupp from Genesis for planning and construction of the surface separator; S. Dorsch and H.P. Billmann for excellent technical assistance and lab work; J. Holm (BioMar) for providing the experimental diet and D. Zimmermann from Amorim for providing the cork particles; Viola Burkhardt-Gehbauer for the SEM pictures and Ute Rucker for performing the physiological assays. The paper benefited greatly from editing of the scientific language by A.J. Beer. This project was funded by the Deutsche Bundesstiftung Umwelt (DBU) (AZ 26128).

\section{LITERATURE CITED}

Badiola M, Mendiola D, Bostock J (2012) Recirculating Aquaculture Systems (RAS) analysis: main issues on management and future challenges. Aquacult Eng 51: 26-35

Bilotta GS, Brazier RE (2008) Understanding the influence of suspended solids on water quality and aquatic biota. Water Res 42:2849-2861

Brinker A (2005) Suspended solids in flow-through aquaculture: dynamics and management. Hartung-Gorre Verlag, Constance

Brinker A, Friedrich C (2012) Fish meal replacement by plant protein substitution and guar gum addition in trout feed. Part II: Effects on faeces stability and rheology. 
Biorheology 49:27-48

Brinker A, Rösch R (2005) Factors determining the size of suspended solids in a flow-through fish farm. Aquacult Eng 33:1-19

Brinker A, Koppe W, Rösch R (2005a) Optimizing trout farm effluent treatment by stabilizing trout feces: a field trial. N Am J Aquacult 67:244-258

Brinker A, Koppe W, Rösch R (2005b) Optimised effluent treatment by stabilised trout faeces. Aquaculture 249: 125-144

Brinker A, Schröder HG, Rosch R (2005c) A high-resolution technique to size suspended solids in flow-through fish farms. Aquacult Eng 32:325-341

Chen YS, Beveridge MCM, Telfer TC, Roy WJ (2003) Nutrient leaching and settling rate characteristics of the faeces of Atlantic salmon (Salmo salar L.) and the implications for modelling of solid waste dispersion. J Appl Ichthyol 19:114-117

Cripps SJ, Bergheim A (2000) Solids management and removal for intensive land-based aquaculture production systems. Aquacult Eng 22:33-56

> Dalsgaard J, Pedersen PB (2011) Solid and suspended/dissolved waste $(\mathrm{N}, \mathrm{P}, \mathrm{O})$ from rainbow trout (Oncorynchus [sic] mykiss). Aquaculture 313:92-99

> Davidson J, Summerfelt ST (2005) Solids removal from a coldwater recirculating system-comparison of a swirl separator and a radial-flow settler. Aquacult Eng 33: $47-61$

Davidson J, Good C, Barrows FT, Welsh C, Kenney PB, Summerfelt ST (2013) Comparing the effects of feeding a grain- or a fish meal-based diet on water quality, waste production, and rainbow trout Oncorhynchus mykiss performance within low exchange water recirculating aquaculture systems. Aquacult Eng 52:45-57

Dolan E, Murphy N, O'Hehir M (2013) Factors influencing optimal micro-screen drum filter selection for recirculating aquaculture systems. Aquacult Eng 56:42-50

FAO (Food and Agriculture Organization of the United Nations) (2014) The state of world fisheries and aquaculture-2014 (SOFIA). FAO, Rome

Gregory NG, Grandin T (2007) Animal welfare and meat production, 2nd edn. CABI, Wallingford

IGKB (Internationale Gewässerschutzkommission für den Bodensee) (2000) Dem Bodensee in den Abflussjahren 1996 und 1997 zugeführte Stofffrachten (Loads discharged into Lake Constance in 1996-1997.). IGKB, Langenargen

Iwama GK, Tautz AF (1981) A simple growth model for salmonids in hatcheries. Can J Fish Aquat Sci 38:649-656

Jensen KO, Denver S, Zanoli R (2011) Actual and potential development of consumer demand on the organic food market in Europe. NJAS - Wageningen J Life Sci 58: 79-84

Editorial responsibility: Catriona MacLeod,

Hobart, TAS, Australia
Klinger D, Naylor R (2012) Searching for solutions in aquaculture: charting a sustainable course. Annu Rev Environ Resour 37:247-276

Levene H (1960) Robust tests for equality of variance. In: Olkin I (ed) Contributions to probability and statistics. Stanford University Press, Palo Alto, CA, p 278-292

$>$ Ling J, Chen S (2005) Impact of organic carbon on nitrification performance of different biofilters. Aquacult Eng 33: 150-162

> Martins CIM, Eding EH, Verdegem MCJ, Heinsbroek LTN and others (2010) New developments in recirculating aquaculture systems in Europe: a perspective on environmental sustainability. Aquacult Eng 43:83-93

McMillan J, Wheaton F, Hochheimer J, Soares J (2003) Pumping effect on particle sizes in a recirculating aquaculture system. Aquacult Eng 27:53-59

> Merino G, Barange M, Blanchard JL, Harle J and others (2012) Can marine fisheries and aquaculture meet fish demand from a growing human population in a changing climate? Glob Environ Change 22:795-806

Michaud L, Blancheton JP, Bruni V, Piedrahita R (2006) Effect of particulate organic carbon on heterotrophic bacterial populations and nitrification efficiency in biological filters. Aquacult Eng 34:224-233

Muir JF, Roberts RJ (eds) (1982) Recent advances in aquaculture. Croom Helm, London \& Canberra, and Westview Press, Boulder, CO

Sachs L (1997) Angewandte Statistik. Springer-Verlag, Berlin

Sokal RR, Rohlf FJ (1994) Biometry: the principles and practices of statistics in biological research, $3^{\text {rd }}$ edn. W. H. Freeman, New York, NY

> Stewart NT, Boardman GD, Helfrich LA (2006) Characterization of nutrient leaching rates from settled rainbow trout (Oncorhynchus mykiss) sludge. Aquacult Eng 35: 191-198

Timmons MB, Ebeling JM, Wheaton FW, Summerfelt ST, Vinci BJ (2002) Recirculating aquaculture systems, $2^{\text {nd }}$ edn. Cayuga Aqua Ventures Llc., Ithaca, NY

Unger J, Brinker A (2013a) Feed and treat: what to expect from commercial diets. Aquacult Eng 53:19-29

Unger J, Brinker A (2013b) Floating feces: a new approach for efficient removal of solids in aquacultural management. Aquaculture 404-405:85-94

van Rijn J (2013) Waste treatment in recirculating aquaculture systems. Aquacult Eng 53:49-56

Welch BL (1947) The generalization of Student's problems when several different population variances are involved. Biometrika 34:28-35

Wickens JF (1981) Water quality requirements for intensive aquaculture: a review. In: Tiews K (ed) Aquaculture in heated effluents and recirculation systems. Proc World Symp, Stavanger, 28-30 May, 1980. Heenemann Verlagsgesellschaft, Berlin, p 28-30

Submitted: May 20, 2015; Accepted: August 12, 2015

Proofs received from author(s): October 13, 2015 